\title{
Occurrence of plant secondary metabolite fingerprints in river waters from Eastern Jutland, Denmark
}

\author{
Mulatu Yohannes Nanusha ${ }^{1,2}$, Martin Krauss ${ }^{1}$, Bettina Gro Sørensen ${ }^{1,2}$, Tobias Schulze ${ }^{1}$, Bjarne W. Strobel ${ }^{3}$ and \\ Werner Brack ${ }^{1,2^{*}}$ (D)
}

\begin{abstract}
Background: A large number of chemicals are constantly introduced to surface water from anthropogenic and natural sources. So far, unlike anthropogenic pollutants, naturally occurring compounds are not included in environmental monitoring programs due to limited knowledge on their occurrence and effects in the environment. Since previous studies suggest that natural compounds might contribute to mixture risks in aquatic ecosystems and for drinking water production, there is a need to increase empirical evidence on the occurrence of these compounds in aquatic systems. To this end, we performed target screening on 160 toxic secondary plant metabolites (PSMs), prioritized in silico for their likelihood of occurrence, persistence, toxicity and mobility in river waters, using liquid chromatography coupled to high resolution mass spectrometry (LC-HRMS). The samples were collected during rain events from three Danish rivers from an area covered by grassland, forest and agricultural crops.

Results: In total, 27 targets belonging to different compound classes such as alkaloids, coumarins and flavonoids were detected, among them 12 compounds, which have not been reported in surface waters before. The most prominent compound class was the group of alkaloids with $41 \%$ of the detected targets, many of them detected in more than $80 \%$ of the samples. Individual compound concentrations were up to several hundred $\mathrm{ng} / \mathrm{L}$ with the neurotoxic alkaloid coniine from poison hemlock and the flavonoid daidzein reaching maximum concentrations of about 400 and $282 \mathrm{ng} / \mathrm{L}$, respectively. In some samples, especially from Vejle river, the rise in concentration of target compounds were associated with increase in the rain intensity and elevated water table in the river.
\end{abstract}

Conclusions: The measured natural toxin concentrations are well within the range of those of synthetic environmental contaminants and need to be considered for the assessment of potential risks on aquatic organisms and drinking water production.

Keywords: Phytotoxins, Plant metabolites, Surface water, Ecotoxicity, Natural toxins, Emerging contaminants

\section{Background}

A myriad of possibly toxic plant secondary metabolites (PSMs) are synthesized by both natural and agricultural vegetation $[16,24]$. They are supporting plant's

\footnotetext{
*Correspondence: werner.brack@ufz.de

${ }^{1}$ Department of Effect-Directed Analysis, Helmholtz Centre for Environmental Research-UFZ, Permoserstraße 15, 04318 Leipzig,

Germany

Full list of author information is available at the end of the article
}

survival and reproductive fitness and function as defense agents (against herbivores, microbes, viruses or competing plants) and signal compounds (to attract pollinating or seed dispersing animals) [32, 77]. The synthesizing plants release these compounds to the environment as leachate, root exudate, and through rain sewers, surface run off and decomposition of plants [3, 4, 20]. According to Günthardt et al. [16], in the environment, many PSMs are mobile which facilitate their transfer to surface
Springer Open

(c) The Author(s) 2021, corrected publication 2021. This article is licensed under a Creative Commons Attribution 4.0 International License, which permits use, sharing, adaptation, distribution and reproduction in any medium or format, as long as you give appropriate credit to the original author(s) and the source, provide a link to the Creative Commons licence, and indicate if changes were made. The images or other third party material in this article are included in the article's Creative Commons licence, unless indicated otherwise in a credit line to the material. If material is not included in the article's Creative Commons licence and your intended use is not permitted by statutory regulation or exceeds the permitted use, you will need to obtain permission directly from the copyright holder. To view a copy of this licence, visit http://creativecommons.org/licenses/by/4.0/. 
waters especially during rain events. Hama and Strobel [20] also reported the transfer of alkaloids from plant to soil and pore water as well as their mobility in soil and decline in concentration with depth. Once PSMs enter the environment, they often show similar properties as anthropogenic aquatic pollutants in terms of mobility, persistence and possibly also ecotoxicity $[17,59]$. Structurally, the metabolites belong to different classes of compounds such as pyrrolizidine alkaloids (PAs) including intermedine and echimidine, coumarins including bergapten and psoralen and flavonoids such as quercetin that might impact on aquatic organisms and human health if exposed [3, 35, 50, 56, 74, 77]. Due to their high toxicity, PAs might be suspected to contribute substantially to toxic risks if wildlife or humans are exposed via dermal contact or ingestion [15]. These compounds are often reported to occur as $\mathrm{N}$-oxides together with their corresponding tertiary alkaloids and are found frequently in some genera of Asteraceae, Boraginaceae and Fabaceae [10]. PAs pose genotoxic and carcinogenic risks to animals including humans $[50,74,76]$ and induce liver injury in livestock [50]. Flavonoids are widely distributed in a variety of plant species including many edible plants as dietary components [44]. Although the majority of natural products are well tolerated, flavonoids and related phytochemicals have been shown to induce neurobehavioral and endocrine disrupting effects. For instance, high doses of quercetin over years have been shown to induce the formation of tumors in mice [5] and may inhibit acetylcholinesterase (AChE) [5].

Phytochemicals (toxins) have been studied in food and feed for decades, but little attention has been paid to their occurrence in the environment $[8,11,24,33]$. Only recently first results on the occurrence of naturally occurring compounds (e.g., PSMs) in water and soil have been reported [17, 19, 21, 25, 48, 49]. Despite the large variety of PSMs that might be released to surface waters, only few compounds have been reported in surface water. To shed more light on PSMs in the aquatic environment, Nanusha et al. [48] studied the impact of surrounding vegetation on the chemical mixture in river water using LC-HRMS non-target screening (NTS) and identified overlapping chemical signals in plant elutriates and potentially impacted river water. The study revealed thousands of overlapping chemical signals, of which the identities of several compounds such as kaempferol, quercetin and apiin, were confirmed in both water and plants confirming vegetation as source for the occurrence of phytochemicals in river water [48]. The study also pointed out the impact of rain intensity on the leaching and run-off of phytochemicals into receiving surface waters. Another study identified the toxic alkaloids lycorine and narciclasine and the photosensitive furanocoumarins bergapten and psoralen in river waters at maximum concentrations of $3 \mu \mathrm{g} / \mathrm{L}$ and $0.5 \mu \mathrm{g} / \mathrm{L}$, respectively [49]. The occurrence of estrogenic isoflavones (e.g., formononetin and daidzein), indole alkaloids (e.g., gramine) and pyrrolizidine alkaloids (e.g., senecionine and senkirkine) in concentrations of up to $55 \mathrm{ng} / \mathrm{L}$ were reported in surface waters from Switzerland [17, 25]. Hama and Strobel [19] detected pyrrolizidine alkaloids such as jacobine, retrorsine and senecionine in the concentration range of $4-270 \mu \mathrm{g} / \mathrm{L}$ in surface water impacted by the high abundance of Senecio Jacobaea L.

We hypothesize that these findings are only the tip of the iceberg and more efforts are needed to explore PSM occurrence in surface water. Thus, to extend the knowledge on the impact of PSMs leaching chemical mixtures into surface waters and to understand the impact of abundant (toxic) plants and agriculture on water quality, we selected three connected rivers in Denmark draining a catchment with agricultural land, forest and grassland with high abundance of Senecio jacobea to unravel the occurrence of phytotoxins in river water.

\section{Materials and methods \\ Water sampling}

Our study addressed the Vejle River (Danish: Vejle $\AA$ ), an approximately $32 \mathrm{~km}$ long river, and its two small tributaries (Kvak Moellebaek and Ballegab Skovbaek streams) near to Vejle Municipality in Eastern Jutland, Denmark with one sampling site each (Fig. 1). Vejle river originates from Engelsholm Lake and flows east through the Vejle River Valley (Danish: Vejle Ådal) until it reaches the City of Vejle. In close vicinity to the sampling sites, the rivers drain agricultural land with barley, wheat and sugarbeet, forest with high abundance of Alnus glutinosa (common alder), Petasites hybridus (butterbur), Symphytum $\times$ uplandicum (comfrey), Urtica dioica (common nettle) and grassland with Senecio Jacobaea L. (ragwort). In close location to the water sampling sites, all the three rivers share the same vegetation and soil, which is sandy (for more information on soil property see Additional file 1: Table S1).

River water was sampled from October to November 2019, which is a typical rain season. Here, the rain season was selected with the hypothesis that rain washes PSMs from the producing plant or during the decay of wilted plant parts to the receiving river water. As noticed during the sampling campaign, the plant species in the surrounding areas were vital at the beginning of the sampling campaign but turned to decay in November. A total of 20 samples of $20 \mathrm{~L}$ of water were extracted on-site at the three sites (see Additional file 1: Table S2) using large volume solid phase extraction (LVSPE) [60] devices from Maxx Mess-und Probenahmetechnik 


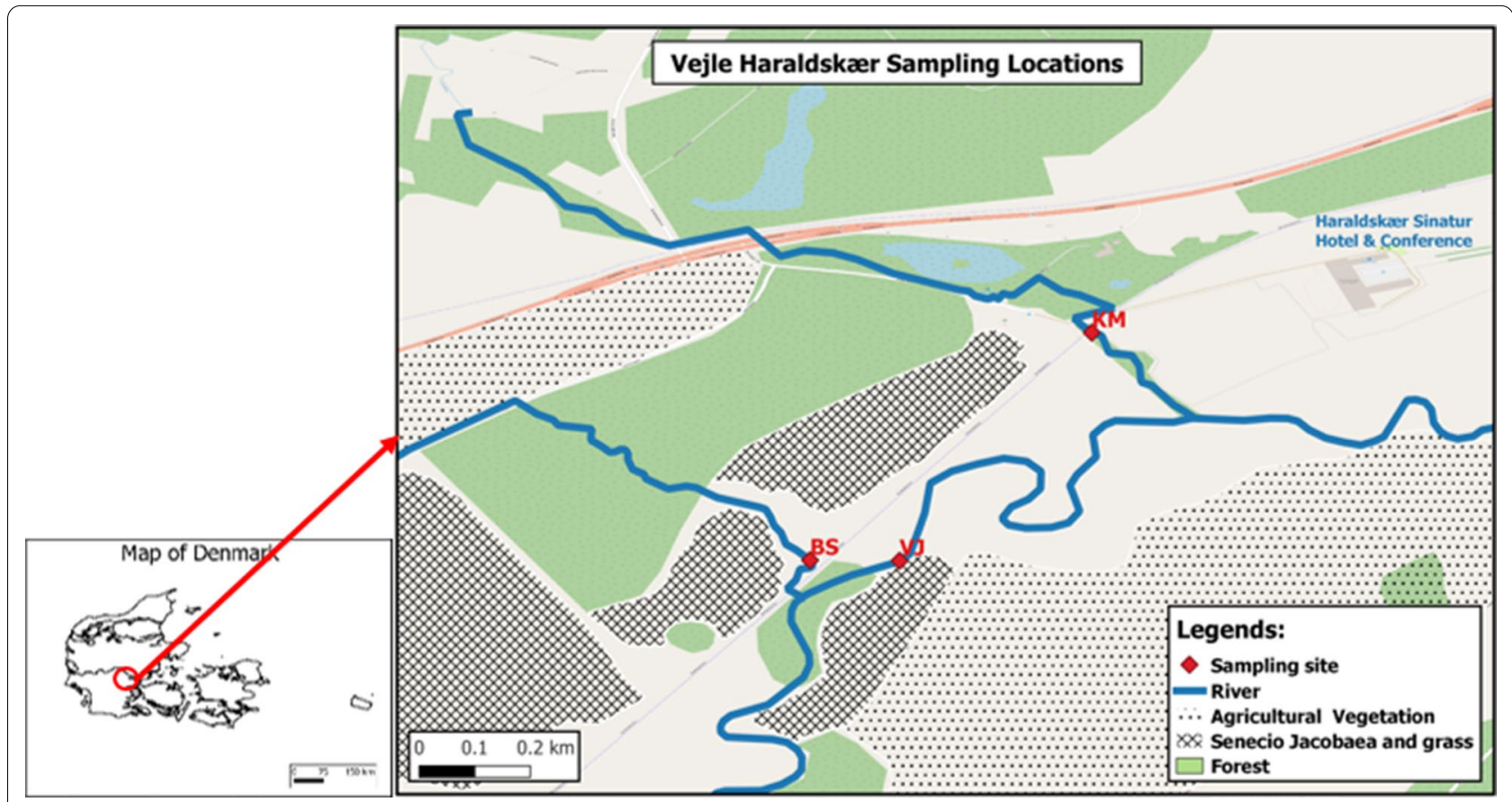

Fig. 1 Map showing water sampling sites. KM Kvak Moellebaek stream, VJVejle river, BS Ballegab Skovbaek stream)

$\mathrm{GmbH}$, Rangendingen, Germany triggered by the rise in water level resulting from rain events (Danish Meteorological Institute www.dmi.dk and www.hydrometri.dk/ hyd/). LVSPE cartridges were filled with $10 \mathrm{~g}$ of Chromabond HR-X sorbent (Macherev-Nagel, Düren, Germany) and loaded with extractable components from $20 \mathrm{~L}$ of river water per rain event for about $3 \mathrm{~h}$ with a flow rate of approximately $3 \mathrm{~mL} / \mathrm{min}$. During the sampling campaign several rain events occurred (see Additional file 1: Table S3), however, only events that created water table rise in the river/streams for about more than $3 \mathrm{~cm}$ were sampled. Extraction cartridges were preconditioned with methanol/ethyl acetate $(1: 1, \mathrm{v} / \mathrm{v})$, methanol and water [66]. All used solvents had LC-MS grade quality. Loaded cartridges were kept at $4{ }^{\circ} \mathrm{C}$ and transported to laboratory. Subsequently, cartridges were purged with nitrogen to remove water, freeze-dried and stored at $-20{ }^{\circ} \mathrm{C}$ for analysis. Blanks were prepared in similar manner as samples using the LVSPE device.

\section{Reagents and chemicals}

LC-MS grade methanol, formic acid and ammonium formate were purchased from Honeywell and LC-MS grade water from Thermo-Fisher. LC-MS grade ethyl acetate and $7 \mathrm{~N}$ ammonia in methanol were obtained from Sigma-Aldrich. Reference standards were purchased from various suppliers with purity higher than $90 \%$ (see $[48,49]$ for detailed information).

\section{Sample preparation}

From each cartridge, the analytes were eluted with methanol/ethyl acetate 1:1 (v/v, $500 \mathrm{~mL}$ each, neutral fraction), methanol containing $2 \%$ of $7 \mathrm{~N}$ ammonia in methanol (500 mL, acidic fraction) and methanol with $1 \%$ of formic acid (500 $\mathrm{mL}$, basic fraction). The $\mathrm{pH}$ of both acidic and basic fractions was adjusted to $7 \pm 0.5$ by adding formic acid or $7 \mathrm{~N}$ ammonia in methanol. The eluates were filtered (GF/F Whatman) to remove remaining precipitates and reduced to dryness using a rotary evaporator $\left(40{ }^{\circ} \mathrm{C}\right.$ water bath temperature) and a gentle stream of nitrogen. Subsequently, the samples were transferred to methanol and adjusted to a final enrichment factor of 1000. For analysis, $100-\mu \mathrm{L}$ aliquots were spiked with $25 \mu \mathrm{L}$ of internal standard mixture (see Additional file 1: Table S4) containing isotope-labelled compounds $(1 \mu \mathrm{g} / \mathrm{mL}), 30 \mu \mathrm{L}$ of methanol and $60 \mu \mathrm{L}$ of water. LVSPE using the same solid phase and following the same procedure showed good recovery (50-123\%) for more than $80 \%$ of 251 organic test compounds covering a broad $\log D$ range from -3.6 to 9.4 [60]. Our target compounds with $\log D$ of -1.7 to 3.7 (Table 1) were well within that range and thus within the domain of this method.

\section{Chemical analysis}

For the chemical analysis, $5 \mu \mathrm{L}$ of the samples were injected into a Thermo Ultimate 3000 LC system (consisting of a ternary pump, autosampler and column oven) 


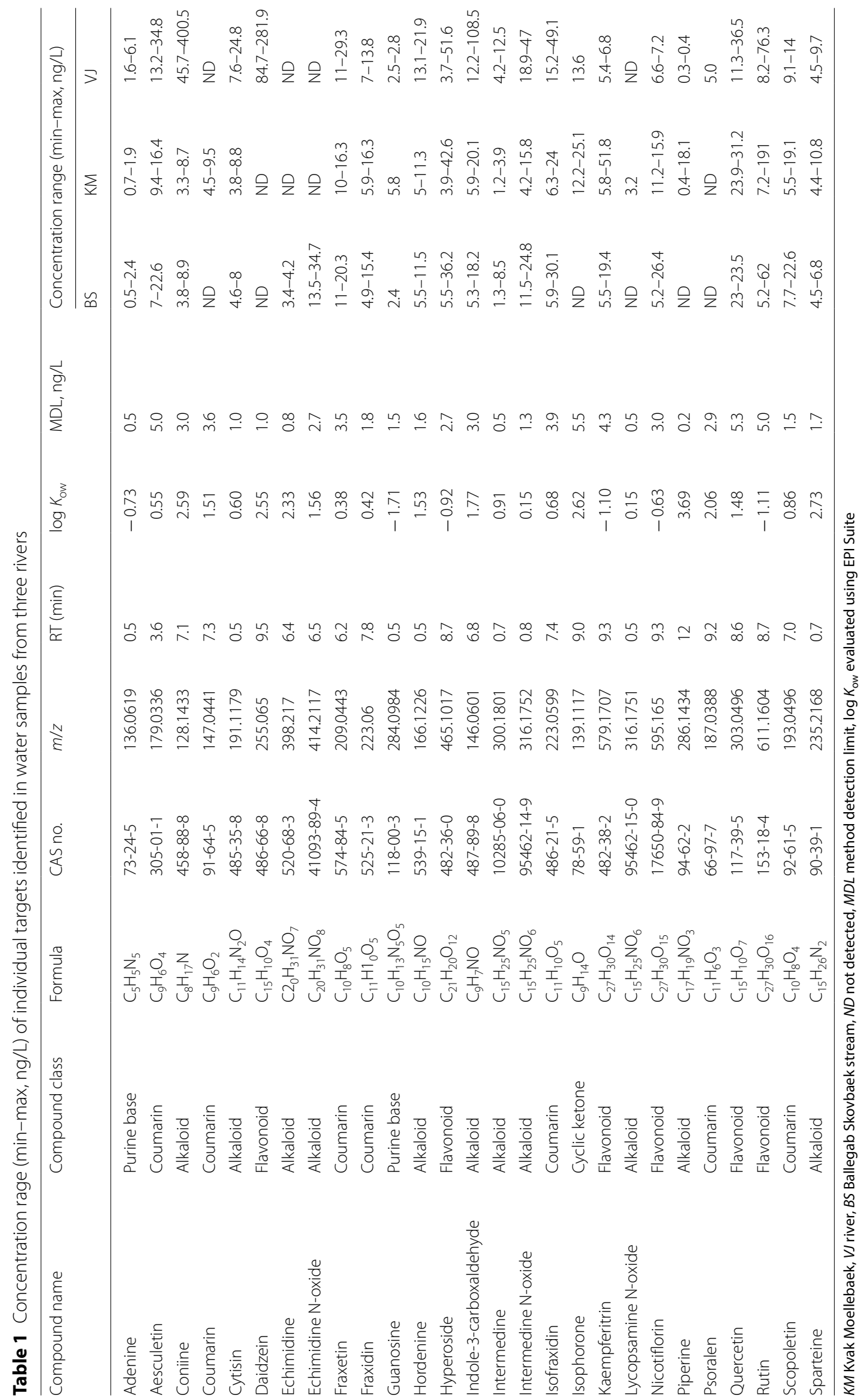


coupled to a quadrupole-orbitrap instrument (Thermo QExactive Plus) equipped with a heated electrospray ionisation (ESI) source. Blanks were treated and analysed exactly in the same way as water samples.

\section{Liquid chromatography}

LC separation was performed on a Kinetex C18 EVO column $(50 \times 2.1 \mathrm{~mm}, 2.6 \mu \mathrm{m}$ particle size $)$ using a gradient elution with $0.1 \%$ of formic acid (eluent A) and methanol containing $0.1 \%$ of formic acid (eluent B) at a flow rate of $300 \mu \mathrm{L} / \mathrm{min}$. After 1 min elution with $5 \% \mathrm{~B}$, the fraction of B was linearly increased to $100 \%$ within $12 \mathrm{~min}$ and $100 \%$ B were kept for $11 \mathrm{~min}$. Subsequently, the column was rinsed with a mixture of isopropanol + acetone 50:50/eluent B/eluent A (85\%/10\%/5\%) to remove hydrophobic matrix constituents from the column. Finally, the column was re-equilibrated to initial conditions for $5.7 \mathrm{~min}$. The column was operated at $40{ }^{\circ} \mathrm{C}$.

\section{Mass spectrometry}

The heated ESI source and the transfer capillary were both operated at $300{ }^{\circ} \mathrm{C}$, with a spray voltage of $3.8 \mathrm{kV}$, a sheath gas flow rate of 45 a.u. and an auxiliary gas flow rate of 1 a.u. The full scan MS1 was recorded in $m / z$ range $100-1500$ with a nominal resolving power of 140,000 (referenced to $\mathrm{m} / \mathrm{z} 200$ ). For metabolite confirmation, data dependent MS/MS acquisition was performed at a resolving power of 70,000 in additional runs. The MS was calibrated externally every 2 days using the calibration mixtures of the vendor. The mass accuracy was always within 5 ppm for all analyses. All MS and MS/MS analyses were performed in ESI positive (ESIpos) and negative (ESIneg) mode.

\section{Target screening}

\section{Qualitative target screening}

For target screening of water samples, the prioritization of target PSMs was mainly built on the previous work by Günthardt et al. [16], identifying plant phytotoxins with a high probability to reach the aqueous environment due to mobility and persistence. Based on in silico predictions, the authors prioritized phytotoxins with half-life longer than 20 days, a $\log D_{\mathrm{OC}}$ (organic carbon-water partition coefficient) below 4.5, reported rodent or aquatic toxicity and high abundance of the producing plant in Switzerland [16]. Out of these PSMs, we selected about 160 target PSMs (as described by Nanusha et al. [48, 49]) based on their commercial availability and cost as well as the probability of occurrence due to the abundance of the plants identified as the origin of some metabolites. Furthermore, only metabolites containing one or more of the elements nitrogen, oxygen and sulfur, in addition to carbon and hydrogen were selected allowing for electrospray ionization and thus LC-HRMS detection.

The LC-HRMS raw data were converted to mzML format using ProteoWizard (version 2.1.0) [26]. The centroid data were subjected to MZmine (version 2.38) for peak detection followed by peak alignment and target compound annotation [34, 46, 52]. Settings for each step of the data processing are given in Additional file 1: Table S5. Further evaluation and visualization were performed using Excel 2013 (Microsoft office) and R (version 3.4.3).

Target compounds were identified by matching $\mathrm{m} / \mathrm{z}$ and retention time between water samples and standard compounds with a mass and retention time tolerance of $5 \mathrm{ppm}$ and $\pm 0.1 \mathrm{~min}$, respectively. To exclude noise and background signals the cut-off intensity was set to $10^{4}$ and data were corrected for blank signals based on seven blanks analyzed together with the samples. Duplicates resulting from multiple annotation were removed manually using peak resolution and intensity. For the tentatively identified target compounds, an inclusion list was developed for data dependent MS/MS acquisition. MS/ MS experiments were conducted on authentic standard compounds and the samples to confirm the chemical structure. Diagnostic MS/MS fragments were matched with the MS/MS of reference standards. For the target compounds with low intensity in unresolved chromatograms, parallel reaction monitoring analysis was conducted for better chromatographic peaks visualization. The XCalibur v4.0.27.10 (Thermo Fisher Scientific) software was used for analysis of extracted ion chromatograms (EICs) and mass spectra (MS1 and MS2).

\section{Quantification of detected targets}

TraceFinder 4.1 (ThermoFisher Scientific) was used for the quantification of the confirmed target compounds using extracted ion chromatograms of the full scan data. In TraceFinder, the use of only one identifier mass (precursor ion) bares the risk of false positive identification and quantification of contaminants. Thus, additional fragment ions were used to confirm the presence of target compounds and to eliminate errors in identification. For some metabolites, ions used for confirmation were not clearly detectable due to low intensity. In such cases, confirmation was complemented using Xcalibur. A series of method-matched calibration standards ranging from 0.5 to $5000 \mathrm{ng} / \mathrm{L}$ were used. All the calibration standards were treated exactly the same way as river water samples. The target compounds were quantified using the internal standards with the nearest retention time. The method detection limits (MDLs) (Table 1) for the detected target compounds were determined following US-EPA procedure [64]. 


\section{Results and discussion}

\section{Occurrence of target compounds in river waters}

In total, 226 peaks were detected with an agreement of the precursor ion mass $(\mathrm{m} / \mathrm{z})$ and retention time with target compounds at mass and retention time tolerance of $5 \mathrm{ppm}$ and $\pm 0.1 \mathrm{~min}$, respectively. Some target compounds were annotated several times due to picking multiple peaks at a single precursor ion mass with given retention time tolerance or due to their different adducts $\left(\mathrm{M}+\mathrm{H}^{+}, \mathrm{M}+\mathrm{NH}_{4}{ }^{+}\right.$and $\left.\mathrm{M}+\mathrm{Na}^{+}\right)$. Removal of duplicates and false positives and peak filtering for intensity and resolution reduced the target list to 138 annotated peaks. Based on additional MS/MS fragment comparison with reference standards, we confirmed the presence of 27 target compounds in all samples from three rivers. The detected compounds represent a wide variety of natural compounds that belong to different compound classes such as alkaloids, coumarins, flavonoids and others, with alkaloids being the prominent compound class. The chemical structures for those compounds not reported previously $[48,49]$ are given in Fig. 2. Identified compounds include the alkaloids coniine, cytisin and intermedine and the coumarins, psoralen and fraxetin. The details on the identified target compounds are given in Additional file 1: Table S6. The samples are named according to the river name, i.e., VJ denotes samples collected from Vejle River, KM denotes Kvak Moellebaek Stream and BS denotes Ballegab Skovbaek Stream.

In all water samples at least 13 co-occurring targets were detected with a maximum of 20 targets in one sample from Kvak Moellebaek stream. Detection frequency of individual targets ranged from 5\% (detection in only one sample) for psoralen and lycopsamine $\mathrm{N}$-oxide to $100 \%$ for fraxidin, indole3-carboxaldehyde, intermedine $\mathrm{N}$-oxide, isofraxidin and scopoletin (Fig. 3). Among the identified targets, $48 \%$ were detected in more than $80 \%$ of the samples, while 19\% (5 metabolites) were detected in all samples from the three rivers. The good agreement between the sampling sites is linked with the similar land use, vegetation type and density in the catchment although the detection frequency of the targets was slightly higher in Vejle river than in the streams Kvak Moellebaek and Ballegab Skovbaek.

\section{Concentration of target compounds}

Table 1 summarizes the concentration range of target compounds detected in samples from the three studied rivers, while the individual concentrations are given in Additional file 1: Table S6. Individual concentrations ranged from 0.4 to 191 , from 0.3 to 400 and from 0.5 to $62 \mathrm{ng} / \mathrm{L}$ in samples from Kvak Moellebaek, Vejle and Ballegab Skovbaek rivers, respectively. Some target compounds were obtained in samples from one site only such as daidzein and psoralen in Vejle river, lycopsamine $\mathrm{N}$-oxide in Kvak Moellebaek stream and coumarin and echimidine $\mathrm{N}$-oxide in Ballegab Skovbaek stream. For many of the detected targets, Vejle river contained highest individual concentrations. This finding is in agreement with the existence of several upstream tributaries contributing to the load. Out of 27 detected compounds, 11 (41\%) were alkaloids with individual concentration ranging from 0.3 to $400 \mathrm{ng} / \mathrm{L}$, followed by coumarins (26\% of detected targets and a concentrations range of 4.5 to $49 \mathrm{ng} / \mathrm{L}$ ) and flavonoids (22\% of the detected target compounds and concentrations from 3.7 to $282 \mathrm{ng} / \mathrm{L}$ ).

\section{Dependence of concentrations on rain intensity}

Figure 4 demonstrates concentration trends for target compounds obtained per river over time reflecting raising water levels and thus rain intensity. Since sampling was triggered by raise in water level due to rain events, the sampling time courses are different for the three rivers with more similarity between Kvak Moellebaek and Vejle rivers (Fig. 4a, b). In Fig. 4, blue color stands for alkaloids, green for coumarins, red for flavonoids and grey for other miscellaneous compounds. Typically, maximum concentrations were obtained in October samples reflecting high rain intensity and probably higher activity of the plants than in November [32]. In general, two trends could be observed including rising concentrations with the rise in water level as observed for Vejle river, which is consistent with the leaching hypothesis at heavy rain events (Fig. 4b) and the reduction over time as observed for Ballegab Skovbaek stream, which is consistent with the decline of vegetation in autumn (Fig. 4c). River Kvak Moellebaek exhibits a kind of overlay of both with a general decline over time but a peak concentration at the most severe rain event (Fig. 4a). In samples from Kvak Moellebaek stream (Fig. 4a), the differences in total concentration of targets were mainly driven by flavonoids, specifically by rutin, while the contribution from coumarins, alkaloids and other miscellaneous compounds remain relatively constant throughout the samples, except in the last sample (KM_19.11.2019). Regarding samples from Vejle river (Fig. 4b), the variation in overall concentration was mainly driven by the alkaloid coniine and the flavonoid daidzein behaving in opposite way throughout the samples. Lower water levels tend to increase daidzein concentrations, while higher water levels increase coniine concentrations. This agrees with the hypothesis that daidzein does not come from plant leachate but from domestic waste due to soya product consumption in households and diluted at high water levels, while coniine behaves as expected for a 


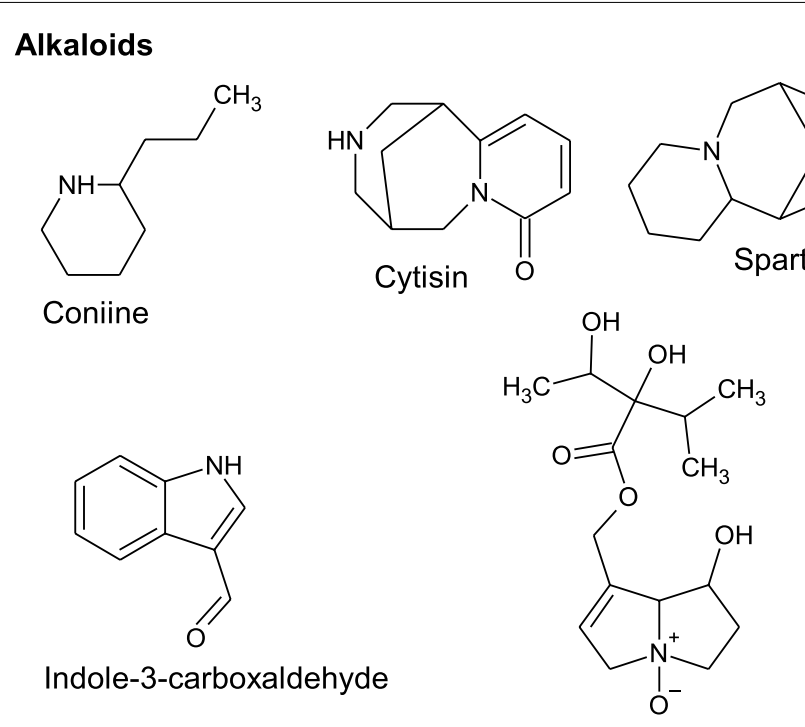

Intermedine $\mathrm{N}$-oxide

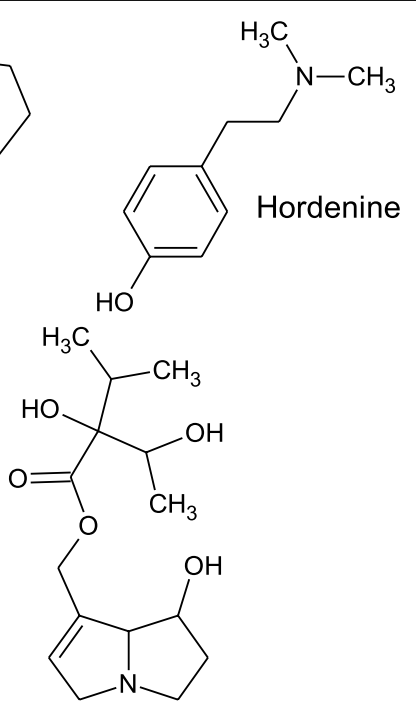<smiles>CC=C(C)C(=O)OC1CCN2CC=C(COC(=O)C(O)(C(C)O)C(C)(C)O)C12</smiles>

Echimidine<smiles>CC=C(C)C(=O)OC1CC[N+]2([O-])CC=C(COC(=O)C(O)(C(C)O)C(C)(C)O)C12</smiles>

Echimidine $\mathrm{N}$-oxide

\section{Flavonoids}<smiles>O=c1c(-c2ccc(O)cc2)coc2cc(O)ccc12</smiles><smiles></smiles>

\section{Coumarins and other compounds}<smiles>COc1cc2ccc(=O)oc2c(O)c1O</smiles>

Fraxetin

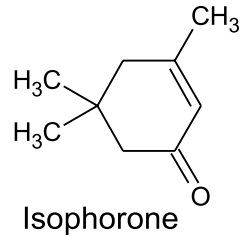

Fig. 2 Chemical structure for some of the detected target compounds (not reported previously by [48, 49]) 


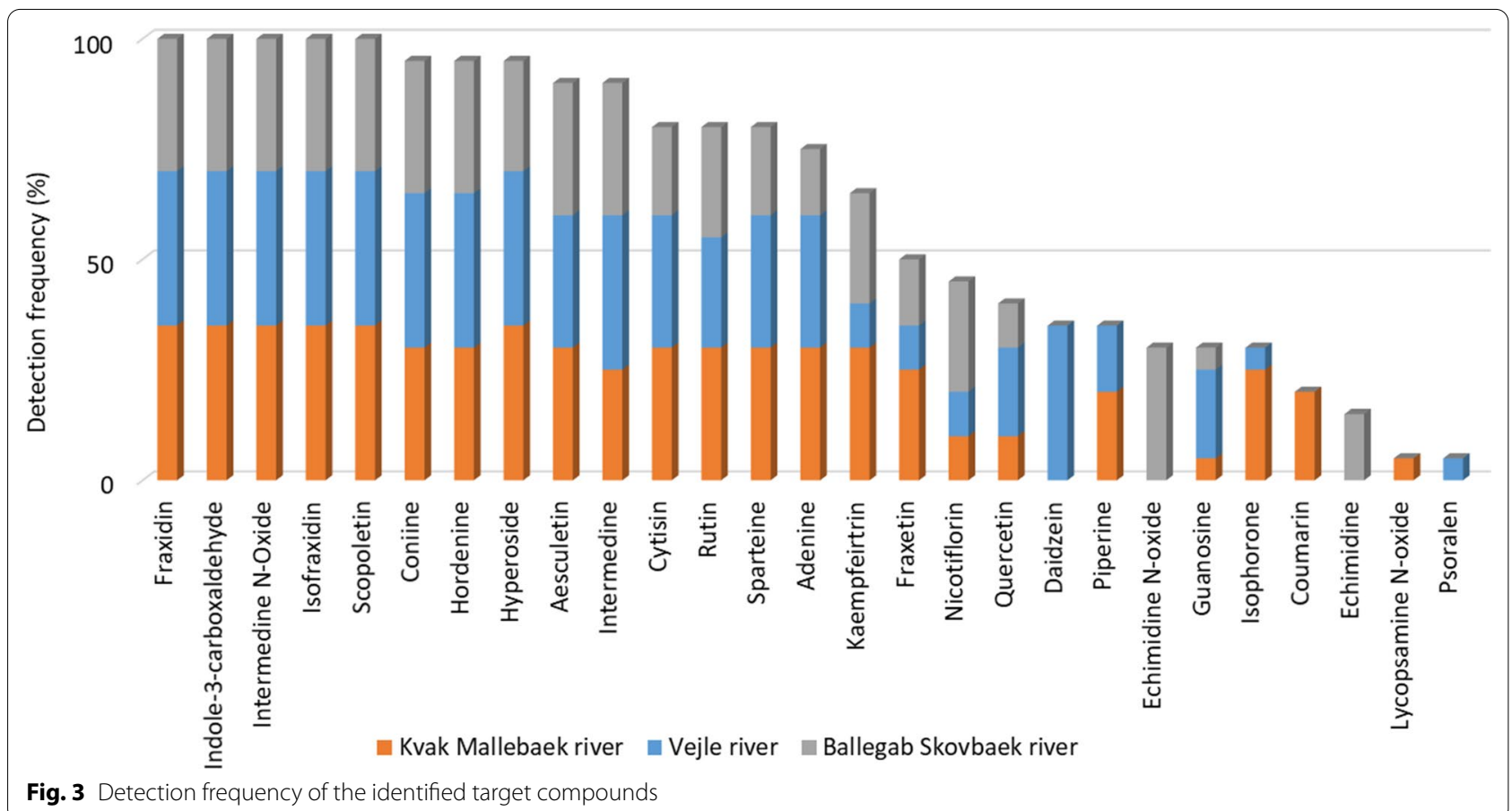

compound leaching from vegetation during rain. Samples from Ballegab Skovbaek stream (Fig. 4c) showed different behavior of concentrations of target compounds with continuous decline over time, from October to November samples.

\section{Distribution of individual targets Alkaloids}

The PAs intermedine and intermedine $\mathrm{N}$-oxide were obtained at detection frequencies of 90 and $100 \%$ and in concentrations up to 12.5 and $47 \mathrm{ng} / \mathrm{L}$, respectively. Other PAs, echimidine, echimidine $\mathrm{N}$-oxide and lycopsamine $\mathrm{N}$-oxide were obtained at lower detection frequency (less than $30 \%$ of the samples) at concentrations of up to $34.7 \mathrm{ng} / \mathrm{L}$. The compounds were previously reported in different Boraginaceae including Symphytum bulbosum, Symphytum officinale and Symphytum tuberosum $[6,7,16,43,55]$. This is in agreement with the abundant presence of Symphytum $\times$ uplandicum along Ballegab Skovbaek and Vejle rivers. Lycopsamine and intermedine extracted from Symphytum officinale were demonstrated to cause adverse effects such as angiectasis at a concentration of $1500 \mathrm{mg} / \mathrm{kg}$ in rats. Similarly hepatic necrosis and ascites were developed by chicken (Gallus gallus domesticus) followed by administration of $1.04 \mathrm{mmol} / \mathrm{kg}$ body weight per day for 7 days in in vivo study [7]. Although, in the environment, these compounds occur at levels that are too low to produce acute liver damage, they are still high enough to be of concern as a possible long-term cause of cirrhosis and liver failure in human and livestock [67]. Interestingly the PAs senecionine, jacobine, erucifoline and seneciphylline that are known to occur in Senecio jacobea have not been detected in the water samples despite the high abundance of this plant $[19,21]$.

The quinolizidine alkaloids, cytisin and sparteine, were detected in $80 \%$ of samples from the three rivers. The former was found at an average concentration of $6,5.2$ and $11.1 \mathrm{ng} / \mathrm{L}$, while the latter reached 5.4, 6 and 7.4 $\mathrm{ng} / \mathrm{L}$ in samples from Ballegab Skovbaek, Kvak Moellebaek and Vejle rivers, respectively (Table 1). The compounds were identified as the main alkaloids from Cytisus scoparius (common broom), but it can also be isolated from several Fabaceae species, including Lupinus, Spartium, and Cytisus [1, 16, 54]. Apart from their numerous pharmacological effects, e.g., cardiovascular and antihypertensive, cytisin and sparteine demonstrated inhibitory effect on the central nicotinic acetylcholine receptors at $\mathrm{IC}_{50}$ of approximately $26 \mu \mathrm{g} / \mathrm{L}$ and $77 \mathrm{mg} / \mathrm{L}$, respectively, based on in vitro studies $[57,69]$.

The phenethylamine alkaloid hordenine was detected in $95 \%$ of samples at an average concentration range of 7.4 to $17.9 \mathrm{ng} / \mathrm{L}$ (Fig. 3 and Additional file 1: Table S6). Most commonly, it is extractable from barley (Hordeum species) providing also the name. However, it can be found in a variety of natural and agricultural plants including grasses $[1,13,30]$. Its detection in the three rivers is in agreement with the abundance of agriculture 


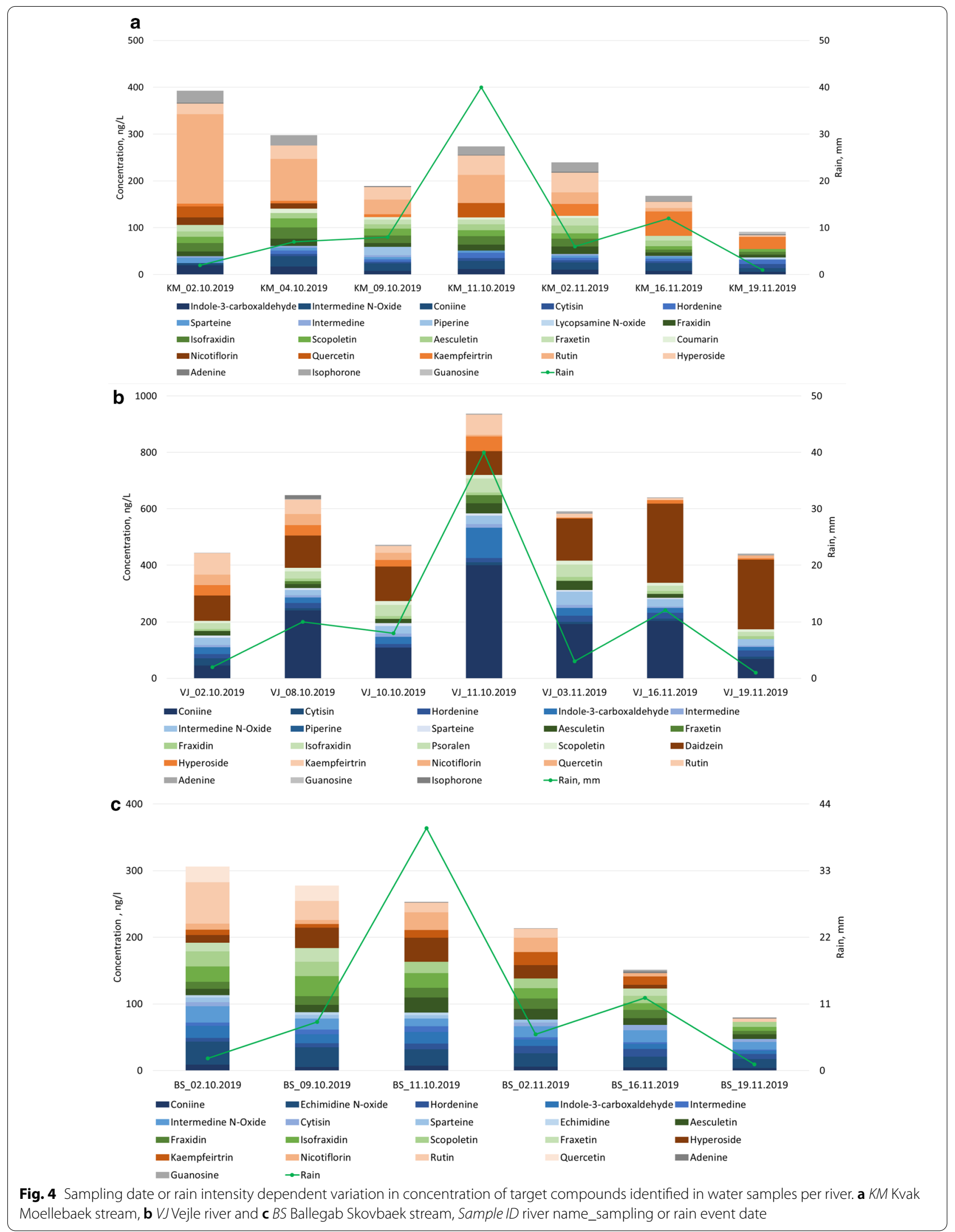


and grass land in the catchment. The compound exhibits numerous pharmacological effects causing respiratory distress in horses at an effect concentration of $2 \mathrm{mg} / \mathrm{kg}$ due to its indirect action as adrenergic drug [13, 30,36]. Hordenine may decrease the UV protection by inhibiting the production of melanin, which plays an important role in protecting skin against ultraviolet light injury [36].

Coniine, a polyketide-derived alkaloid, was detected in $95 \%$ of samples from three sites (Fig. 3). It was detected at an average concentration range of 6 to $179.7 \mathrm{ng} / \mathrm{L}-$ the highest occurring in samples from Vejle river (Additional file 1: Table S6). Coniine is known to occur in toxic Apiaceae such as Conium maculatum $[1,16,42]$. However, there was no evidence for the occurrence of such plants alongside of the sampled rivers. It is a nicotinic acetylcholine receptor antagonist inhibiting the nervous system, eventually causing death $[28,29,42]$. Coniine's most famous victim is Socrates who was sentenced to death by poison chalice containing poison hemlock in 399 BC [28]. Following the administration of coniine, signs of maternal intoxication were observed in both rat and rabbit [12].

Piperine, a piperidine alkaloid, was detected in samples from the rivers Kvak Moellebaek and Vejle in concentrations up to $18.1 \mathrm{ng} / \mathrm{L}$. It was also previously reported in river waters from Germany at concentration up to 338 ng/L [49]. Piperine is a major component of Piper species (e.g., Piper nigrum, Piper longum, Piper officinarum and Piper retrofractum), which are globally marketed as flavoring agent and cooking spice with a long history of human health benefits and a wide consumption $[58,62]$. Thus, the input of piperine to the river water is very likely due to human activities, while no plants containing these compounds in the catchments are known. Besides its numerous medicinal benefits such as antioxidant, antithyroid and antiasthmatic activity, piperine may also have adverse effects including hemorrhagic necrosis and edema in gastrointestinal tract, urinary bladder and adrenal glands observed in animal tests with rats $[9,51]$. Zwart et al. [79] detected piperine in waste water treatment plant effluents and classified it as one of the most potent nonsteroidal estrogens.

Indole-3-carboxaldehyde, an indole alkaloid, was detected in all samples from all three rivers $(100 \%$ detection frequency-Fig. 3). It was quantified within the concentration range of $5.3-108.5 \mathrm{ng} / \mathrm{L}$ in samples, the maximum concentration was measured in Vejle river. It's extractable from several plants such as barley (Hordeum vulgare) $[1,53]$

\section{Flavonoids}

Daidzein was detected in all samples from Vejle river, only, up to a maximum concentration of $281.9 \mathrm{ng} / \mathrm{L}$. It was previously reported in creeks from Switzerland up to a concentration of $5.5 \mathrm{ng} / \mathrm{L}$ [17], up to $40 \mathrm{ng} / \mathrm{L}$ in rivers in Iowa [37], while concentrations in the River Danube downstream of untreated wastewater discharge reached almost $500 \mathrm{ng} / \mathrm{L}$ [38]. Daidzein is a naturally occurring isoflavonoid phytoestrogen belonging to the non-steroidal estrogens and is mainly derived from the Fabaceae family plants such as soybean, peas and red clover $[1,5$, $25,41]$. Through its way from the origin, Vejle river flows long distance (approximately $32 \mathrm{~km}$ ) and passes through various farmland, which may contain such plants as the origin of the compound. Alternatively, its detection in river could likely be associated with human activities, since leguminous plants are widely used as sources of food. This hypothesis is supported by the fact that higher water levels in Vejle River are accompanied by lower daidzein concentrations (resulted from dilution) and supporting the release of daidzein from municipal wastewater rather than leaching from vegetation as driver of concentration changes. Daidzein was investigated for its potential to alter fertility and cause developmental toxicity to the reproductive tract in female rats. It has been reported to affect various neurobiological regulatory mechanisms such as behavior, cognition, growth, development and reproduction [2, 40].

Rutin and hyperoside were obtained with a detection frequency of $>80 \%$ (Fig. 3) and concentrations up to $190.9 \mathrm{ng} / \mathrm{L}$ (Table 1 ). Whereas their aglycone quercetin in $40 \%$ of samples at concentration range of 11.3 to $36.5 \mathrm{ng} / \mathrm{L}$. Hyperoside is a typical component of Hypericum perforatum, quercetin from Quercus (oak), while rutin is synthesized by both plants [1] as well as by Symphytum officinale [63]. The detection of rutin at high concentration (190.9 ng/L), among flavonoids, could be linked to the abundant presence of Symphytum $\times$ uplandicum. The occurrence of quercetin and rutin could also be connected with the high abundance of Urtica dioica along the rivers [1]. Recently, hyperoside and quercetin were reported in river water as well as in extracts of Galanthus nivalis and Fraxinus excelsior abundantly present in close vicinity (upstream) to the water sampling sites, confirming that the occurrence of these compounds in river water is linked to the surrounding vegetation [48]. The authors found quercetin and hyperoside in river waters at considerable concentrations up to 2.5 and $4 \mu \mathrm{g} / \mathrm{L}$, respectively [48]. Vila-Nova et al. [68] isolated the flavonoids quercetin and rutin from Dimorphandra gardneriana and Platymiscium floribundum and in vitro assay determined acetylcholinesterase enzyme (AChE) inhibition with $\mathrm{EC}_{50}$ of 10.6 and $43.3 \mu \mathrm{g} / \mathrm{mL}$, respectively. Numerous pharmacological applications were reported for hyperoside, for example for the improvement of the cardiac function and for the 
treatment of liver fibrosis [71, 72]. The same compound displayed acetylcholinesterase inhibition and depression of the central nervous system $[18,23]$.

The kaempferol glycosides nicotiflorin and kaempferitrin were detected in samples from all three rivers with a detection frequency of 65 and $45 \%$, and maximum concentrations of $26.4 \mathrm{ng} / \mathrm{L}$ and $51.8 \mathrm{ng} / \mathrm{L}$, respectively (Table 1). Nicotiflorin and kaempferitrin were previously reported in river water from Germany at maximum concentrations of approximately 2 and $1 \mu \mathrm{g} / \mathrm{L}$, respectively [48]. Nicotiflorin is synthesized by Urtica dioica [1]. Both compounds decrease arterial blood pressure and heart beat rate and have hepatoprotective effects [22]. Nicotiflorin was found to protect against memory dysfunction and oxidative stress in multi-infarct dementia model rats $[22,31]$. A study by Zhang et al. [78] showed that kaempferitrin competitively inhibited human liver microsomal Cytochrome P450 1A2 activity.

\section{Coumarins}

The coumarins isofraxidin, asculetin, scopoletin and fraxidin were obtained in more than $80 \%$ of the samples, fraxetin in $50 \%$, while coumarin and psoralen were found in less than $30 \%$ of samples. The concentrations of individual coumarins were in the range between 4.5 and $49.1 \mathrm{ng} / \mathrm{L}$. Isofraxidin, asculetin, scopoletin and fraxidin have been previously detected in water samples from a German floodplain forest at concentrations up to $157 \mathrm{ng} / \mathrm{L}$ [49]. The same study reported psoralen at lower detection frequency but with concentrations up to $224 \mathrm{ng} / \mathrm{L}$ in river waters and thus 45 times greater than the concentration $(5 \mathrm{ng} / \mathrm{L})$ in the present study. Coumarins are synthesized by several plants, especially by those of the Apiaceace family [39, 47, 61, 73]. Simple coumarins have been found to be biologically active with anti-stress, anti-fatigue, anti-gastric ulcer, anti-depressive, immuno-enhancing and anti-inflammatory effects [73, 75]. Scopoletin is mainly synthesized by Scopolia species; however, its presence in river water could also be caused by the massive presence of Urtica dioica [1]. In vitro, scopoletin exhibited acetylcholinesterase inhibition with $\mathrm{IC}_{50}$ of $169 \mu \mathrm{g} / \mathrm{L}$ [27]. The exposure to the furanocoumarin psoralen combined with long wave UV radiation causes cytotoxic reactions (e.g., erythema) and genotoxic responses by binding to nucleobases in DNA $[56,70]$.

\section{Other miscellaneous compounds}

The purine nucleosides, adenine and guanosine were obtained in samples from three rivers at detection frequencies of 80 and 30\%, respectively, and maximum concentrations of about $6 \mathrm{ng} / \mathrm{L}$ (Table 1), which are by three orders of magnitude lower than concentrations previously detected in German river waters [48]. Both compounds are components of all living organisms. Isophorone, synthesized by Brassica hirta [45] and Prunus armeniaca L. [14], was detected in samples from Kvak Moellebaek and Vejle rivers at up to $25.1 \mathrm{ng} / \mathrm{L}$ (Table 1). Its presence in river water originates most likely from human activities, since it is widely used solvent and chemical intermediate. There is no evidence for the presence of plants containing these compounds in the catchments. Chronic (long-term) exposure to isophorone in humans can cause dizziness, fatigue and depression. Animal studies indicate that long-term inhalation of high concentrations of isophorone causes central nervous system effects [65].

\section{Conclusion}

This study screened for 160 PSMs in the River Vejle, Denmark, and two tributaries. In total 27 phytochemicals from different compound classes including alkaloids, flavonoids and coumarins were detected in rivers with a minimum of 13 target compounds per sample. Among these PSMs 12 compounds have not been detected in surface waters before. Maximum concentrations of individual compounds reached up to several hundred nanogram per liter. The toxic PAs (intermedine, inchemedine and their $\mathrm{N}$-oxide forms), polyketide-derived alkaloid (coniine) and quinolizidine alkaloids (cytisin and sparteine) were among the detected compounds. Detailed spatial and temporal sampling may help to comprehensively explore the seasonal variation of PSMs in aquatic system as well as their fate and distribution in the environment. The study adds to a series of recent results suggesting that possibly toxic PSMs occur in relevant concentrations in European surface waters and should be considered in monitoring and risk assessment of water resources. Aquatic toxicity data for PSMs are extensively lacking but are required for involving these compounds in the assessment of risks to aquatic organisms and for eliminating risks to human health during drinking water production.

\section{Abbreviations}

LCHRMS: Liquid chromatography coupled to high resolution mass spectrometry; PSMs: Plant secondary metabolites; KM: Kvak Moellebaek stream; VJ: Vejle river; BS: Ballegab Skovbaek stream; PAs: Pyrrolizidine alkaloids; MDL: Method detection limit; ND: Not detected; LVSPE: Large volume solid phase extraction; Dl: Direct injection. 


\section{Supplementary Information}

The online version contains supplementary material available at https://doi. org/10.1186/s12302-021-00464-4.

Additional file 1. Occurrence of plant secondary metabolite fingerprints in river waters from Eastern Jutland, Denmark.

\section{Acknowledgements}

The authors would like to thank European Commission for funding the NaToxAq project (Grant Agreement ID: 722493); analyses were run on the high-throughput platform CITEPro (Chemicals in the Environment Profiler) funded by the Helmholtz Association. A free academic license of JChem for Office (Excel) and Marvin/JChem 17.21.0, 2019 ChemAxon (https://www. chemaxon.com) were used for the structure based property prediction. The authors would also like to thank Dr. Roman Gunold (UFZ - Leipzig) for installing and operating LVSPE sampling machines, Bo Levesen (Vejle municipality) and Erik Jønsson (Vejle municipality) taking care of LVSPE machine and samples during sampling period as well as Dr. Thomas D. Bucheli, Carina D. Schönsee and Barbara F. Günthardt (Agroscope, Zürich) for providing analytical standards.

\section{Authors' contributions}

MYN: conceptualization, sampling, investigation, experimental analysis, data evaluation and visualization, drafted the original version. MK: conceptualization, investigation, writing — review and editing; WB: conceptualization, supervision, writing — review and editing. BGS: conceptualization, editing and reviewing. TS: LVSPE sampling, editing and reviewing. BWS: sampling site selection, sample collection and sampling, editing and reviewing. All authors read and approved the final manuscript.

\section{Funding}

Open Access funding enabled and organized by Projekt DEAL. This study has received funding from the European Union's Horizon 2020 research and innovation programme under the Marie Sklodowska-Curie Grant Agreement No. 722493.

\section{Availability of data and materials}

The datasets obtained and analyzed in the current study are available from the corresponding author on reasonable request.

\section{Ethics approval and consent to participate}

Not applicable.

\section{Consent for publication}

Not applicable.

\section{Competing interests}

The authors declare that they have no competing interests.

\section{Author details}

1 Department of Effect-Directed Analysis, Helmholtz Centre for Environmental Research-UFZ, Permoserstraße 15, 04318 Leipzig, Germany. ${ }^{2}$ Department of Evolutionary Ecology and Environmental Toxicology, Faculty of Biological Sciences, Goethe University Frankfurt, Max-von-Laue Str. 13, 60438 Frankfurt am Main, Germany. ${ }^{3}$ Department of Plant and Environmental Science, University of Copenhagen, Thorvaldsensvej 40, 1871 Frederiksberg, Denmark.

Received: 24 November 2020 Accepted: 5 February 2021

Published online: 27 February 2021

\section{References}

1. Afendi FM, Okada T, Yamazaki M, Hirai-Morita A, Nakamura Y, Nakamura K, Ikeda S, Takahashi H, Altaf-UI-Amin M, Darusman LK, Saito K, Kanaya S (2012) KNApSAcK family databases: integrated metabolite-plant species databases for multifaceted plant research. Plant Cell Physiol 53(2):e1. https://doi.org/10.1093/pcp/pcr165
2. Ahmed T, Javed S, Tariq A, Budzyńska B, D'Onofrio G, Daglia M, Nabavi SF, Nabavi SM (2017) Daidzein and its effects on brain. Curr Med Chem 24(4):365-375. https://doi.org/10.2174/0929867323666161101140214

3. Al-Shatti AH, Redha A, Suleman P, Al-Hasan R (2014) The allelopathic potential of Conocarpus lancifolius (Engl.) leaves on dicot (Vigna sinensis L.), Monocot (Zea mays L.) and soil-Borne pathogenic fungi. Am J Plant Sci 5(19):2889-2903. https://doi.org/10.4236/ajps.2014.519304

4. Aulakh MS, Wassmann R, Bueno C, Kreuzwieser J, Rennenberg H (2001) Characterization of root exudates at different growth stages of ten rice (Oryza sativa L.) cultivars. Plant Biol 3(2):139-148. https://doi.org/10. 1055/s-2001-12905

5. Ayaz M, Sadiq A, Junaid M, Ullah F, Ovais M, Ullah I, Ahmed J, Shahid M (2019) Flavonoids as prospective neuroprotectants and their therapeutic propensity in aging associated neurological disorders. Front Aging Neurosci. https://doi.org/10.3389/fnagi.2019.00155

6. Brauchli J, Lüthy J, Zweifel U, Schlatter C (1982) Pyrrolizidine alkaloids from Symphytum officinale $L$. and their percutaneous absorption in rats. Experientia 38(9):1085-1087. https://doi.org/10.1007/BF01955382

7. Brown AW, Stegelmeier BL, Colegate SM, Gardner DR, Panter KE, Knoppel EL, Hall JO (2016) The comparative toxicity of a reduced, crude comfrey (Symphytum officinale) alkaloid extract and the pure, comfrey-derived pyrrolizidine alkaloids, lycopsamine and intermedine in chicks (Gallus gallus domesticus). J Appl Toxicol 36(5):716-725. https://doi.org/10.1002/ jat.3205

8. Clauson-Kaas F, Ramwell C, Hansen HCB, Strobel BW (2016) Ptaquiloside from bracken in stream water at base flow and during storm events. Water Res 106:155-162. https://doi.org/10.1016/j.watres.2016.09.049

9. Derosa G, Maffioli P, Sahebkar A (2016) Piperine and its role in chronic diseases. Adv Exp Med Biol 928:173-184. https://doi.org/10.1007/ 978-3-319-41334-1_8

10. Ehmke A, von Borstel K, Hartmann T (1988) Alkaloid N-oxides as transport and vacuolar storage compounds of pyrrolizidine alkaloids in Senecio vulgaris L. Planta 176(1):83-90. https://doi.org/10.1007/bf00392483

11. Fletcher MT, Netzel G (2020) Food safety and natural toxins. Toxins 12(4):236. https://doi.org/10.3390/toxins12040236

12. Forsyth CS, Frank AA (1993) Evaluation of developmental toxicity of coniine to rats and rabbits. Teratology 48(1):59-64. https://doi.org/10.1002/ tera.1420480110

13. Frank M, Weckman TJ, Wood T, Woods WE, Tai CL, Chang SL, Ewing A, Blake JW, Tobin T (1990) Hordenine: pharmacology, pharmacokinetics and behavioural effects in the horse. Equine Vet J 22(6):437-441. https:// doi.org/10.1111/j.2042-3306.1990.tb04312.x

14. Gomez E, Ledbetter CA, Hartsell PL (1993) Volatile compounds in apricot, plum, and their interspecific hybrids. J Agric Food Chem 41(10):16691676. https://doi.org/10.1021/jf00034a029

15. Griffiths MR, Strobel BW, Hama JR, Cedergreen N (2021) Toxicity and risk of plant-produced alkaloids to Daphnia magna. Environ Sci Eur 33(1):10. https://doi.org/10.1186/s12302-020-00452-0

16. Günthardt BF, Hollender J, Hungerbühler K, Scheringer M, Bucheli TD (2018) Comprehensive toxic plants-phytotoxins database and its application in assessing aquatic micropollution potential. J Agric Food Chem 66(29):7577-7588. https://doi.org/10.1021/acs.jafc.8b01639

17. Günthardt BF, Schönsee CD, Hollender J, Hungerbühler K, Scheringer $M$, Bucheli TD (2020) "Is there anybody else out there?"-First insights from a suspect screening for phytotoxins in surface water. Chimia (Aarau) 74(3):129-135. https://doi.org/10.2533/chimia.2020.129

18. Haas JS, Stolz ED, Betti AH, Stein AC, Schripsema J, Poser GL, Rates SM (2011) The anti-immobility effect of hyperoside on the forced swimming test in rats is mediated by the D2-like receptors activation. Planta Med 77(4):334-339. https://doi.org/10.1055/s-0030-1250386

19. Hama JR, Strobel BW (2019) Pyrrolizidine alkaloids quantified in soil and water using UPLC-MS/MS. RSC Adv 9(52):30350-30357. https://doi.org/ 10.1039/C9RA05301H

20. Hama JR, Strobel BW (2020) Natural alkaloids from narrow-leaf and yellow lupins transfer to soil and soil solution in agricultural fields. Environ Sci Eur 32(1):126. https://doi.org/10.1186/s12302-020-00405-7

21. Hama JR, Strobel BW (2021) Occurrence of pyrrolizidine alkaloids in ragwort plants, soils and surface waters at the field scale in grassland. Sci Total Environ 755(Pt 1):142822. https://doi.org/10.1016/j.scitotenv.2020. 142822 
22. Harborne JB, Baxter H (1999) The handbook of natural flavonoids, vol 1-2. Wiley, New York

23. Hernandez MF, Falé PLV, Araújo MEM, Serralheiro MLM (2010) Acetylcholinesterase inhibition and antioxidant activity of the water extracts of several Hypericum species. Food Chem 120(4):1076-1082. https://doi.org/ 10.1016/j.foodchem.2009.11.055

24. Hoerger CC, Schenzel J, Strobel BW, Bucheli TD (2009) Analysis of selected phytotoxins and mycotoxins in environmental samples. Anal Bioanal Chem 395(5):1261-1289. https://doi.org/10.1007/s00216-009-3088-y

25. Hoerger CC, Wettstein FE, Hungerbühler K, Bucheli TD (2009) Occurrence and origin of estrogenic isoflavones in Swiss River waters. Environ Sci Technol 43(16):6151-6157. https://doi.org/10.1021/es901034u

26. Holman JD, Tabb DL, Mallick P (2014) Employing ProteoWizard to convert raw mass spectrometry data. Curr Protoc Bioinform 46:13-24. https://doi. org/10.1002/0471250953.bi1324s46

27. Hostettmann K, Borloz A, Urbain A, Marston A (2006) Natural product inhibitors of acetylcholinesterase. Curr Org Chem 10(8):825-847. https:// doi.org/10.2174/138527206776894410

28. Hotti H, Rischer H (2017) The killer of Socrates: coniine and related alkaloids in the plant kingdom. Molecules. https://doi.org/10.3390/molec ules22111962

29. Hotti H, Seppänen-Laakso T, Arvas M, Teeri TH, Rischer H (2015) Polyketide synthases from poison hemlock (Conium maculatum L.). FEBS J 282(21):4141-4156. https://doi.org/10.1111/febs.13410

30. Hoult AH, Lovett JV (1993) Biologically active secondary metabolites of barley. III. A method for identification and quantification of hordenine and gramine in barley by high-performance liquid chromatography. J Chem Ecol 19(10):2245-2254. https://doi.org/10.1007/bf00979661

31. Huang J-L, Fu S-T, Jiang Y-Y, Cao Y-B, Guo M-L, Wang Y, Xu Z (2007) Protective effects of nicotiflorin on reducing memory dysfunction, energy metabolism failure and oxidative stress in multi-infarct dementia model rats. Pharmacol Biochem Behav 86(4):741-748. https://doi.org/10.1016/j. pbb.2007.03.003

32. Isah T (2019) Stress and defense responses in plant secondary metabolites production. Biol Res 52(1):39. https://doi.org/10.1186/ s40659-019-0246-3

33. Jensen PH, Pedersen RB, Svensmark B, Strobel BW, Jacobsen OS, Hansen HC (2009) Degradation of the potato glycoalkaloid alpha-solanine in three agricultural soils. Chemosphere 76(8):1150-1155. https://doi.org/ 10.1016/j.chemosphere.2009.04.008

34. Katajamaa M, Oresic M (2005) Processing methods for differential analysis of LC/MS profile data. BMC Bioinform 6:179. https://doi.org/10.1186/ 1471-2105-6-179

35. Khan H, Marya AS, Kamal MA, Patel S (2018) Flavonoids as acetylcholinesterase inhibitors: current therapeutic standing and future prospects. Biomed Pharmacother 101:860-870. https://doi.org/10.1016/j.biopha. 2018.03.007

36. Kim SC, Lee JH, Kim MH, Lee JA, Kim YB, Jung E, Kim YS, Lee J, Park D (2013) Hordenine, a single compound produced during barley germination, inhibits melanogenesis in human melanocytes. Food Chem 141(1):174-181. https://doi.org/10.1016/j.foodchem.2013.03.017

37. Kolpin DW, Hoerger CC, Meyer MT, Wettstein FE, Hubbard LE, Bucheli TD (2010) Phytoestrogens and mycotoxins in lowa streams: an examination of underinvestigated compounds in agricultural basins. J Environ Qual 39(6):2089-2099. https://doi.org/10.2134/jeq2010.0121

38. König M, Escher BI, Neale PA, Krauss M, Hilscherová K, Novák J, Teodorović I, Schulze T, Seidensticker S, Kamal Hashmi MA, Ahlheim J, Brack W (2017) Impact of untreated wastewater on a major European river evaluated with a combination of in vitro bioassays and chemical analysis. Environ Pollut 220(Part B):1220-1230. https://doi.org/10.1016/j.envpol.2016.11. 011

39. Lake BG (1999) Coumarin metabolism, toxicity and carcinogenicity: relevance for human risk assessment. Food Chem Toxicol 37(4):423-453. https://doi.org/10.1016/S0278-6915(99)00010-1

40. Lamartiniere CA, Wang J, Smith-Johnson M, Eltoum IE (2002) Daidzein: bioavailability, potential for reproductive toxicity, and breast cancer chemoprevention in female rats. Toxicol Sci 65(2):228-238. https://doi. org/10.1093/toxsci/65.2.228

41. Liu M, Yanagihara N, Toyohira Y, Tsutsui M, Ueno S, Shinohara Y (2007) Dual effects of daidzein, a soy isoflavone, on catecholamine synthesis and secretion in cultured bovine adrenal medullary cells. Endocrinology 148(11):5348-5354. https://doi.org/10.1210/en.2007-0073

42. López TA, Cid MS, Bianchini ML (1999) Biochemistry of hemlock (Conium maculatum L.) alkaloids and their acute and chronic toxicity in livestock: a review. Toxicon 37(6):841-865. https://doi.org/10.1016/S0041-0101(98) 00204-9

43. Mei N, Guo L, Fu PP, Fuscoe JC, Luan Y, Chen T (2010) Metabolism, genotoxicity, and carcinogenicity of comfrey. J Toxicol Environ Health B Crit Rev 13(7-8):509-526. https://doi.org/10.1080/10937404.2010.509013

44. Miean KH, Mohamed S (2001) Flavonoid (myricetin, quercetin, kaempferol, luteolin, and apigenin) content of edible tropical plants. J Agric Food Chem 49(6):3106-3112. https://doi.org/10.1021/jf000892m

45. Miyazawa M, Kawata J (2006) Identification of the main aroma compounds in dried seeds of Brassica hirta. J Nat Med 60(1):89-92. https://doi. org/10.1007/s11418-005-0009-z

46. Müller E, Huber C, Beckers LM, Brack W, Krauss M, Schulze T (2020) A data set of 255,000 randomly selected and manually classified extracted ion chromatograms for evaluation of peak detection methods. Metabolites. https://doi.org/10.3390/metabo10040162

47. Nakamura K, Shimura N, Otabe Y, Hirai-Morita A, Nakamura Y, Ono N, UIAmin MA, Kanaya S (2013) KNApSAcK-3D: a three-dimensional structure database of plant metabolites. Plant Cell Physiol 54(2):e4. https://doi.org/ 10.1093/pcp/pcs186

48. Nanusha MY, Krauss M, Brack W (2020) Non-target screening for detecting the occurrence of plant metabolites in river waters. Environ Sci Eur 32(1):130. https://doi.org/10.1186/s12302-020-00415-5

49. Nanusha MY, Krauss M, Schönsee CD, Günthardt BF, Bucheli TD, Brack W (2020) Target screening of plant secondary metabolites in river waters by liquid chromatography coupled to high-resolution mass spectrometry (LC-HRMS). Environ Sci Eur 32(1):142. https://doi.org/10.1186/ s12302-020-00399-2

50. Neuman MG, Cohen L, Opris M, Nanau RM, Hyunjin J (2015) Hepatotoxicity of pyrrolizidine alkaloids. J Pharm Pharm Sci 18(4):825-843. https://doi. org/10.18433/j3bg7j

51. Piyachaturawat P, Glinsukon T, Toskulkao C (1983) Acute and subacute toxicity of piperine in mice, rats and hamsters. Toxicol Lett 16(3-4):351359. https://doi.org/10.1016/0378-4274(83)90198-4

52. Pluskal T, Castillo S, Villar-Briones A, Orešič M (2010) MZmine 2: modular framework for processing, visualizing, and analyzing mass spectrometrybased molecular profile data. BMC Bioinform 11(1):395. https://doi.org/ 10.1186/1471-2105-11-395

53. Puri B, Hall A, Baxter H, Harborne JB, Moss GP (1998) Phytochemical dictionary: a handbook of bioactive compounds from plants, 2nd edn. CRC Press, Boca Raton

54. Rosenmeier L, Kjær ED, Nielsen LR (2013) The Scotch broom, Cytisus scoparius (Fabaceae), a paradox in Denmark - an invasive plant or endangered native species? Bot J Linn Soc 171(2):429-440. https://doi.org/10. 1111/j.1095-8339.2012.01319.x

55. Salehi B, Sharopov F, Boyunegmez Tumer T, Ozleyen A, Rodríguez-Pérez C, Ezzat SM, Azzini E, Hosseinabadi T, Butnariu M, Sarac I, Bostan C, Acharya K, Sen S, Nur Kasapoglu K, Daşkaya-Dikmen C, Özçelik B, Baghalpour N, Sharifi-Rad J, Valere Tsouh Fokou P, Cho WC, Martins N (2019) Symphytum species: a comprehensive review on chemical composition, food applications and phytopharmacology. Molecules 24(12):2272. https://doi.org/10. 3390/molecules24122272

56. Schlatter J, Zimmerli B, Dick R, Panizzon R, Schlatter C (1991) Dietary intake and risk assessment of phototoxic furocoumarins in humans. Food Chem Toxicol 29(8):523-530. https://doi.org/10.1016/0278-6915(91) 90044-8

57. Schmeller T, Sauerwein M, Sporer F, Wink M, Müller WE (1994) Binding of quinolizidine alkaloids to nicotinic and muscarinic acetylcholine receptors. J Nat Prod 57(9):1316-1319. https://doi.org/10.1021/np50111a026

58. Schnabel A, Cotinguiba F, Athmer B, Yang C, Westermann B, Schaks A, Porzel A, Brandt W, Schumacher F, Vogt T (2020) A piperic acid CoA ligase produces a putative precursor of piperine, the pungent principle from black pepper fruits. Plant J 102(3):569-581. https://doi.org/10.1111/tpj. 14652

59. Schönsee CD, Bucheli TD (2020) Experimental determination of octanolwater partition coefficients of selected natural toxins. J Chem Eng Data 65(4):1946-1953. https://doi.org/10.1021/acs.jced.9b01129 
60. Schulze T, Ahel M, Ahlheim J, Aït-Aïssa S, Brion F, Di Paolo C, Froment J, Hidasi AO, Hollender J, Hollert H, Hu M, Kloß A, Koprivica S, Krauss M, Muz M, Oswald P, Petre M, Schollée JE, Seiler T-B, Shao Y, Slobodnik J, Sonavane M, Suter MJF, Tollefsen KE, Tousova Z, Walz K-H, Brack W (2017) Assessment of a novel device for onsite integrative large-volume solid phase extraction of water samples to enable a comprehensive chemical and effect-based analysis. Sci Total Environ 581-582:350-358. https://doi.org/ 10.1016/j.scitotenv.2016.12.140

61. Shinbo Y, Nakamura Y, Altaf-UI-Amin M, Asahi H, Kurokawa K, Arita M, Saito K, Ohta D, Shibata D, Kanaya S (2006) KNApSAcK: a comprehensive species-metabolite relationship database. In: Saito K, Dixon RA, Willmitzer L (eds) Plant metabolomics. Springer, Berlin, pp 165-181. https://doi.org/ 10.1007/3-540-29782-0_13

62. Shoba G, Joy D, Joseph T, Majeed M, Rajendran R, Srinivas PSSR (1998) Influence of piperine on the pharmacokinetics of curcumin in animals and human volunteers. Planta Med 64(04):353-356. https://doi.org/10. 1055/s-2006-957450

63. Tahirovic I, Rimpapa Z, Cavar S, Huseinovic S, Muradic S, Salihovic M, Sofic E (2010) Content of some phenolic acids and rutin in the leaves and roots of Symphytum officinale L. Planta Med 76(12):P293. https://doi.org/10. 1055/s-0030-1264591

64. US-EPA (2011) 40 CFR Part 136, Appendix B to Part 136-Definition and procedure for the determination of the method detection limit-revision 1.11. 40.

65. USA-ATSDR (2018) Toxicological profile for isophorone. Agency for Toxic Substances and Disease Registry (ATSDR), Atlanta, GA

66. Välitalo P, Massei R, Heiskanen I, Behnisch P, Brack W, Tindall AJ, Du Pasquier D, Küster E, Mikola A, Schulze T, Sillanpää M (2017) Effect-based assessment of toxicity removal during wastewater treatment. Water Res 126:153-163. https://doi.org/10.1016/j.watres.2017.09.014

67. van Egmond HP (2004) Natural toxins: risks, regulations and the analytical situation in Europe. Anal Bioanal Chem 378(5):1152-1160. https://doi. org/10.1007/s00216-003-2373-4

68. Vila-Nova NS, Morais SM, Falcão MJC, Bevilaqua CML, Rondon FCM, Wilson ME, Vieira IGP, Andrade HF (2012) Leishmanicidal and cholinesterase inhibiting activities of phenolic compounds of Dimorphandra gardneriana and Platymiscium floribundum, native plants from Caatinga biome. Pesquisa Veterinária Brasileira 32:1164-1168

69. Villalpando-Vargas F, Medina-Ceja L (2016) Sparteine as an anticonvulsant drug: evidence and possible mechanism of action. Seizure 39:49-55. https://doi.org/10.1016/j.seizure.2016.05.010

70. Walter JF, Gange RW, Mendelson IR (1982) Psoralen-containing sunscreen induces phototoxicity and epidermal ornithine decarboxylase activity.
J Am Acad Dermatol 6(6):1022-1027. https://doi.org/10.1016/s01909622(82)70086-6

71. Wang L, Yue Z, Guo M, Fang L, Bai L, Li X, Tao Y, Wang S, Liu Q, Zhi D, Zhao $H$ (2016) Dietary flavonoid hyperoside induces apoptosis of activated human LX-2 hepatic stellate cell by suppressing canonical NF-kB signaling. Biomed Res Int 2016:1068528. https://doi.org/10.1155/2016/1068528

72. Wang X, Liu Y, Xiao L, Li L, Zhao X, Yang L, Chen N, Gao L, Zhang J (2018) Hyperoside protects against pressure overload-induced cardiac remodeling via the AKT signaling pathway. Cell Physiol Biochem 51(2):827-841. https://doi.org/10.1159/000495368

73. Whang WK, Park HS, Ham I, Oh M, Namkoong H, Kim HK, Hwang DW, Hur SY, Kim TE, Park YG, Kim JR, Kim JW (2005) Natural compounds, fraxin and chemicals structurally related to fraxin protect cells from oxidative stress. Exp Mol Med 37(5):436-446. https://doi.org/10.1038/emm.2005.54

74. Wiedenfeld H (2011) Plants containing pyrrolizidine alkaloids: toxicity and problems. Food Addit Contam A 28:282-292

75. Witaicenis A, Seito LN, Di Stasi LC (2010) Intestinal anti-inflammatory activity of esculetin and 4-methylesculetin in the trinitrobenzenesulphonic acid model of rat colitis. Chem Biol Interact 186(2):211-218. https://doi.org/10.1016/j.cbi.2010.03.045

76. Yaber Grass MA, Leicach SR (2012) Changes in Senecio grisebachii pyrrolizidine alkaloids abundances and profiles as response to soil quality. J Plant Interact 7(2):175-182. https://doi.org/10.1080/17429145.2011. 591504

77. Yang L, Wen K-S, Ruan X, Zhao Y-X, Wei F, Wang Q (2018) Response of plant secondary metabolites to environmental factors. Molecules 23(4):762. https://doi.org/10.3390/molecules23040762

78. Zhang N, Liu J, Chen Z, Dou W (2019) In vitro inhibitory effects of kaempferitrin on human liver cytochrome P450 enzymes. Pharm Biol 57(1):571-576. https://doi.org/10.1080/13880209.2019.1656257

79. Zwart N, Nio SL, Houtman CJ, de Boer J, Kool J, Hamers T, Lamoree MH (2018) High-throughput effect-directed analysis using downscaled in vitro reporter gene assays to identify endocrine disruptors in surface water. Environ Sci Technol 52(7):4367-4377. https://doi.org/10.1021/acs. est.7b06604

\section{Publisher's Note}

Springer Nature remains neutral with regard to jurisdictional claims in published maps and institutional affiliations.

\section{Submit your manuscript to a SpringerOpen ${ }^{\circ}$ journal and benefit from:}

- Convenient online submission

- Rigorous peer review

- Open access: articles freely available online

- High visibility within the field

- Retaining the copyright to your article

Submit your next manuscript at $\boldsymbol{\nabla}$ springeropen.com 